\title{
Application of the PEE Model to essay composition in an IELTS preparation class
}

\section{Aplicación del Modelo PEE a la composición de ensayos en una clase para el Examen IELTS}

Ender Orlando Velasco Tovar ${ }^{1}$

Citation / Para citar este artículo: Velasco, E. O. (2015). Application of the PEE Model to essay composition in an IELTS preparation class. Colomb. Appl. Linguist. J., 17(1), pp. 98-113

Received: 22-Aug-2014 / Accepted: 25-Nov-2014

DOI: http://dx.doi.org/10.14483/udistrital.jour.calj.2015.1.a07

\begin{abstract}
Based on two case studies, this study investigates the application of the Point, Explanation, Example (PEE) model to essay composition in a multi-lingual IELTS preparation class. This model was incorporated into an eight-week programme of instruction to ESL adults in London, England. Students preparing for the IELTS exam were asked to write pre- and post-instruction essays on a given topic within 40 minutes. Employing the IELTS band descriptors (IELTS, 2013) and analyses of coherence and cohesion in line with Systemic Functional Linguistic concepts (Halliday \& Matthiessen, 2004; McCarthy, 1991), samples of students' writing were analysed. Data from students' pre- and postinstruction interviews was also gathered and analysed. The findings of this study suggest that the PEE model is to some extent effective in improving the essay composition performance of IELTS students, in particular in the area of cohesion and coherence. Students find the PEE model useful in regard to the clarity and structure that the model seems to add to their essays.
\end{abstract}

Keywords: cohesion and coherence, essay writing, IELTS, PEE model

\section{Resumen}

Basándose en dos casos, este estudio investiga la aplicación del modelo Point, Explanation, Example (PEE) a la composición de ensayos en una clase de preparación para el examen IELTS. Este modelo fue incorporado a un programa de ocho semanas de instrucción de ESL para adultos en Londres, Inglaterra. Estudiantes que se estaban preparando para el examen IELTS escribieron ensayos antes y después de la intervención pedagógica en un tiempo límite de 40 minutos. Basado en los estándares descriptores de bandas IELTS (IELTS, 2013) y análisis de coherencia y cohesión en línea con conceptos de Systemic Functional Linguistic (Halliday \& Matthiessen, 2004; McCarthy, 1991), muestras de los escritos fueron analizadas. Datos de entrevistas realizadas antes y después de la intervención pedagógica también fueron recolectados y analizados. Los resultados de este estudio indican que el modelo PEE es de cierta forma eficaz en el mejoramiento de la capacidad de composición de ensayos de los estudiantes IELTS, en particular en el área de coherencia y cohesión. Los estudiantes parecen encontrar el modelo útil con relación a la claridad y estructura que el modelo aparenta dar a sus ensayos.

Palabras clave: coherencia y cohesión, escritura de ensayos, IELTS, modelo PEE

1 Universidad de La Sabana, Bogotá, Colombia. velasco_ender@yahoo.co.uk 


\section{Introduction}

[M]y overall assessment of the academic standard of [this] essay is 'weak', meriting a score in the low 40's on our marking scale. My reason for this is essentially because of the disorganized manner of presentation of the content. The information is presented in a 'jumbled-up' fashion. I felt a need to do a scissors-and-paste job on the essay, reordering its content so as to introduce a logical flow to the argument, something which is sorely lacking in its present form. (Wall, Nickson, Jordan, Allwright \& Houghton, 1988, p.119)

The above quote is a subject tutor's reaction when asked to comment on an essay produced by an ESL student enrolled in a course at a UK university. Hence, being able to write academic essays that meet certain standards is undoubtedly of significant importance for ESL students who are hoping to undertake higher education (HE) studies in English-speaking countries.

In order to be accepted into HE programmes, ESL students usually have to demonstrate their English proficiency through examinations such as the IELTS or TOEFL. The focus of this study will be on the essay part of the task 2 of the Academic IELTS exam.

Issues regarding ESL students' writing abilities are widely known. It is sometimes assumed that by having met the language requirement for an $\mathrm{HE}$ course through IELTS or other means, ESL students may be equipped with the necessary study skills and writing proficiency required to undertake academic programmes. Unfortunately, this does not seem to be the case, and harsh critiques have been made regarding ESL students' inability to write at the tertiary level (Horner E Min-Zhan, 1999; Keck, 2006; Olivas E Li, 2006; Woodrow, 2006; Yu, 2009).

In an attempt to alleviate some of the essaywriting issues ESL students encounter even before entering tertiary education, this study aimed to investigate the application of the Point, Explanation, Example (PEE) model to essay composition in a multi-lingual IELTS preparation class. This model was incorporated into an eight-week programme of instruction to ESL adults in London, England. The data collection instruments included analyses of students' essays before and after the instruction and pre/post instruction interviews.

\section{Literature review}

It has long been recognised that ESL students struggle with essay writing in L2 for a few reasons: the marked differences between the registers of written and spoken English (Biber, 1988); the high cultural, linguistic and pragmatic demands essays pose on EFL students (Gleason, 1999; Golder \& Coirier, 1996); the language-specific tag attached to argumentative writing (Neff-van E Dafouz-Milne, 2008); and the negative washback resulting from writing under exam conditions (Messick, 1996). It could then be assumed that IELTS students are likely to be affected by similar issues when writing essays as part of their exams.

\section{Task 2 of the Academic IELTS Test}

A number of studies have investigated the task 2 of the Academic IELTS writing module (Archibald, 2002; Brown, 1998; Coomber, 1998; Elder E O'Loughlin, 2003; Green E Weir, 2002, 2003; Moore \& Morton, 1999). However, they have mainly focused on approaches to preparation, impact of preparation programmes on candidates' performance, and score gains in relation to time spans, as opposed to the type instruction imparted to the learners to facilitate the teaching-learning of IELTS-related essay composition. This may suggest that other types of studies, perhaps of a more qualitative nature, could provide insights into how the process of essay writing can be facilitated to IELTS students, particularly if students are expected to employ more complex argumentation models at university e.g. Ramsay, Maier and Price's (2010) Assertion, Evidence, Reasoning (AER) model.

\section{Cohesion and coherence}

Halliday and Hasan (1976) have coined the term "texture" (p.2) to define the properties of a text. These properties are in turn defined by the concepts of cohesion and coherence. The former concept entails how the components in a text are bound together to form a whole unit, while the latter has to do with 
how a text is related to its social and cultural context (Eggins, 2004). There are four types of cohesionthrough references, lexis, conjunctions, and ellipsis (see Halliday \& Matthiessen, 2004, pp. 532-578 for a detailed explanation). Another element of cohesion is thematic patterns (McCarthy, 1991), or the way themes are organised in a text to orientate readers.

Cohesion and coherence are used in IELTS as the criterion to determine whether or not information, ideas, and language are properly linked and organised in the essay message, and whether or not the message in an essay is clear and flows naturally (UCLES, 2007).

\section{The PEE Model}

The PEE model is defined as neither a theory nor an approach to writing essays, but instead as "a model guideline [...] of how to structure a paragraph with a topic sentence and to develop that sentence through the appropriate use of explanations and examples" (Cole, 2013, para. 7). The figure below illustrates how this model may be applied.

Figure 1. Representation of the PEE model from Cole (2013)

"[POINT] There are those who argue that the internet has had an extremely positive influence on communication. [EXPLANATION] They say this because in the past it was sometime impossible to call people in other countries on the telephone, but now it is relatively simple to use a program such as Skype to talk to them for free or to send an email. [EXAMPLE] A good example here are the students who go to study abroad and are able to send messages home with no difficulty, when in the past they would have had to buy stamps and go to the post office which was much harder and more expensive."

While the PEE model seems a straight forward concept, there appear to be some discrepancies regarding its definition. For example, while Cole (2013) refers to the first E in PEE as "Example," other authors refer to it as "Evidence" (BBC, 2013). Equally, while the former author calls PEE a "model," the latter calls it a "technique," and others also call it a "chain" (TES, 2008).

It appears as though 'evidence' (following BBC and TES's definition) is most commonly associated with quotations to back up main ideas of literary essays carried out by English native-speaker students at the Key Stage 3 level in the UK. This can be clearly seen in simplistic explanations about the technique regularly found in material used to prepare English native-speaker students for their English GCSE exams, either as formal preparation (CGP, 2012, p.16), or as exam tips (BBC, 2013; TES, 2008). Yet, many IELTS course books and preparation materials oft en seem to fail to provide the same kind of simplistic explanations (e.g. Harrison \& Whitehead, 2006; Jakeman \& McDowell, 2004; May, 2004), although other resources provide explanations regarding coherence in writing and ways of introducing topics and main ideas, and ways to develop an argument (e.g. Black \& Capel, 2006; Jakeman \& McDowell, 1999). Thus, it could be inferred that if English native-speaker students are trained from an early age to use the PEE model as part of their essay-writing skills, IELTS students should also receive the same kind of training, particularly if they are expected to write essays at university in the future.

\section{The PEE Model in ESL writing teaching theory}

The PEE model could be framed within the "Paragraph Pattern Approach" (Raimes, cited in Matsuda \& Silva, 2010, p. 239), an approach more concerned with organisation of writing above the sentence level and how topic and secondary sentences are put together in order to form paragraphs and ultimately whole texts.

The PEE model fits well within the process approach to teaching ESL writing, as opposed to the model or genre ones (see Bathia, 1993; Hyland, 2000, 2003, 2006; Sidaway, 2006; Swales, 1990, 2004 for work on genre).

While process writing is concerned with activities such as drafting, editing, teacher's or peers' feedback, encouragement of expression of individuality, use of previous schemata, and writing fluency over accuracy (Flower \& Hayes, 1977; Scrivener, 2011; Ur, 2012; White \& Arndt, 1991), product writing is concerned with the rhetoric, content, organisation and linguistic features of written texts in order to replicate conventions and generate parallel texts (Steele, 1992; White, 1980). 
There are contradictory views regarding which ESL writing teaching approach works best. Some studies and accounts have found process writing effective in improving students' writing abilities (Bello, 1997; Jarvis, 2002), whereas other studies have found genre writing more useful (Cheng, 2008; Dudley-Evans, 1994; Kongpetch, 2006). Other language professionals have found a combination of approaches the better option (Davies, 1988; Gabrielatos, 2000a, 2000b, 2000c).

A question could be posed about the effectiveness of the nature of knowledge acquired by students through these approaches when writing under exam conditions. There could be issues with the practicalities of re-drafting or using a model when sitting high-stakes proficiency tests. Thus, it is here where the PEE model could potentially serve as a practical tool to help IELTS students compose an essay that is cohesive and coherent in a relatively constrained period of time.

\section{Methodology}

\section{Research design}

It is hypothesised that the PEE model could benefit IELTS students' overall essay-composition performance. To test this hypothesis, teaching material based on the PEE model was designed and delivered over a period of eight weeks to a group of adult multilingual ESL students preparing for the IELTS exam in London, England.

The aim of this study was to investigate the application of the PEE model to essay composition following a case study approach (Denscombe, 2010; Freebody, 2006; Yin, 1994), with the view that this choice would enable the teacher-researcher to "[...] carry out an investigation where other [strategies] such as experiments - [were] either not practicable or not ethically justifiable [...]." (Bill, 2010, p. 11). That is, I felt that if control and experimental groups had been used within the same population, it would have been unprincipled from a teacher's point of view to deprive certain students of instruction that could have potentially been beneficial for the development of the participants' essay writing skills.
The study addressed three questions: Is the PEE model effective in improving students' IELTS essay-composition performance? If yes above, what area in particular does the PEE model help students with? What are the IELTS students' views on the usefulness of the PEE model after the instruction?

\section{Research population}

The IELTS preparation class employed in this study was held in a language centre in London, England. It was made up of twelve adult multilingual female ESL students between the ages of 21 and 32. All the students were first-time IELTS takers and the length and type of ESL instruction received prior to joining the study varied greatly. The sample for this study consisted of two adult females. The first student (hereafter referred to as JR) was originally from Latvia. She spoke Russian and Latvian as L1. The second student (hereafter referred to as AL) was originally from Germany. She spoke German as L1 and Polish and Russian as L2.

\section{Data collection instruments}

Essays and interviews were employed to collect data. Handwritten essays from the sampled students were collected at two stages-before and after the instruction. Students were given 40 minutes to write their essays on both occasions.

Although there are mixed views about using the same assessment instrument in a study before and after the instruction (Kozloff, 2014; Yuan-Shan \& Shao-Wen, 2011), employing the same instrument was deemed appropriate because this would be an effective way of exploring potential changes e.g. lexical relations.

Semi-structured interviews were also implemented before and after the instruction.

\section{Data analysis and interpretation}

The framework for analysing the essays was based on the IELTS band descriptors for coherence and cohesion and task response (IELTS, 2013). Comments on essays were also supported by analyses of coherence and cohesion 
in line with Halliday and Matthiessen (2004) and McCarthy's (1991) concepts to pinpoint specific examples of progression or regression regarding references, conjunctive relations, lexical chains, and thematic patterns.

Interviews were implemented and recorded. Students' interviews were then transcribed and analysed employing a relational analysis of proximity of concepts (Wilkinson E Birmingham, 2003, pp. 76-87). The proximity of relationships between concepts was based on matters such as strength (i.e. weak or strong relationship) and connotation (i.e. positive or negative association).

\section{Data collection stages}

In week one, the pre-instruction IELTS-related essay was implemented. Students wrote an essay on the topic of 'views on engaging children in paid work,' with a minimum of 250 words, in 40 minutes, without any aids. The pre-instruction interviews were also planned and implemented.

In week two, initial essays were prepared and analysed for cohesion and coherence to assess students' composition skills before the instruction. The initial interviews were transcribed verbatim, coded, and analysed. The analysis of data was the basis to inform the content included in the subsequent instruction. A crucial aspect here was to carry out the interviews after the students had written their initial essays, to avoid giving them clues as to what a well-written essay should entail.

In weeks three through seven, three workshops incorporating the PEE model were designed and implemented. These workshops were mainly based on the PEE model, but also included elements of thematic patterns, how to introduce ideas in essays (Jakeman \& McDowell, 1999), essay question types in IELTS, and general essay planning strategies. These workshops were incorporated into the IELTS preparation course and were not delivered as separate sessions.

In week eight, students rewrote the pre-instruction essay under the same conditions as in week one, without looking at the original piece of writing.
Essays from the two case studies were prepared and analysed. In the same week, the post-instruction interviews were planned and implemented. These were also transcribed, coded, and analysed.

\section{Findings}

\section{Case study 1}

The findings of this case study appeared to suggest that the PEE model was seemingly effective in improving JR's IELTS-essay composition performance, in particular in the area of cohesion and coherence. This was identified in both her essay analyses and interviews. For example, JR's initial essay in week one (appendix A) showed that although she had used paragraphs correctly, a clear central theme had not been presented adequately in each paragraph. The themes introduced in paragraphs seemed random and unrelated to one another, which made the information look rather incoherent and with a lack of overall progression, e.g. "Beside of that to get married for money is illegal, you can be fined or punished - getting to the prison." (lines 10-12), something that JR also seemed to recognise in her post-instruction interview

\section{"[...] here in the initial essay it's just something that I don't know what I'm trying to say, I don't understand myself."}

There was a tendency to include irrelevant details in JR's initial essay and the use of further clarifications and/or concrete examples to support themes was non-existent. This was deemed as a weakness in terms of cohesion and coherence in her essay analysis, which she also put forward in her post-instruction interview

\footnotetext{
"[...] in the first one, when I was writing I didn't explain the meaning, so I did a mess through the whole essay [...] because I haven't used any words and it wasn't... the first one... it wasn't... uhm... perfect, I mean (untranscribable) no any cohesion and coherence [...]"
}

Regarding lexical cohesion, $12 \%$ of words entered into lexical relations in JR's initial essay, as shown in table one below. 
By contrast, JR's final essay in week eight (appendix B) showed that her attempt to apply the PEE model in various sections of her text, i.e. in the second, third, and fourth paragraphs (lines 7-15, 1621 and 22-29 respectively) seemed to give her overall argument better organisation, progression, and clarity e.g. [POINT] "...understand the value of money..." (lines 7-8), [EXPLANATION] "... have an idea how hard parents are working to get money" (lines 11-12), [EXAMPLE] ".. instead of asking for an Iphone or Ipad [...] ask for a cheaper electronic device." (lines 12-15). This seeming improvement in the cohesion and coherence of her final essay was something JR also agreed with in her post-instruction interview

\section{"[...] in the second I used the PEE model to create my new essay. [...] I read it again and everything is clear for me. [...] Uhm... argument, I really...uhm... I put a point, I explain it and did put in examples." \\ "Interviewer: Right. So out of the four... sort of [IELTS] descriptors, which one do you feel the PEE model has helped you the most with? JR: Coherence and cohesion."}

Regarding lexical cohesion, $18 \%$ of words formed lexical strings in JR's final essay, as shown in table two below.

The findings of this case study suggested that JR found the PEE model particularly useful in regard to the clarity that can be added to an IELTSrelated essay, as articulated in her post-instruction interview

"Yes, I do feel that it is useful [...] because it is, well... you need to write your essay clearly and that makes the essay look clearly. I mean, you always need to uhm... explain what you meaning, you cannot leave just... you cannot say ' $A$ ' without saying the ' $B$ ' after'

\section{Case study 2}

Once again, the findings of this case study appeared to suggest that the PEE model was to some extent effective in improving AL's IELTS-essay composition performance in terms of cohesion and coherence. This was also identified in both the essay analyses and interviews. For instance, AL's initial essay in week one (appendix C) showed that although she had presented relevant ideas and her argument was explicit, the information and ideas had not been arranged coherently and there was no clear organisation, progression, linking, or flow in the response due to the fact that she had written a single clustered paragraph. Her whole essay seemed rather hectic, difficult to read, and it was difficult to determine where the breaks between main ideas were as shown in this excerpt:

[...] Children should go to school. If they can learn something by doing another activity for some time

Table 1. Lexical Relations Initial Essay Case Study 1

Numbers refer to lines in the essay. Ties between items are classification unless otherwise indicated with $\mathrm{X}$ (expectancy). This analysis is by no means exhaustive.

people (2) - children (3) - parents $(4,8)$ - children $(9,21)$ - mother $(27)$ - mothers (29) - children (32) $=9$

to get married for money (10) - illegal (11) - fined-punished-prison (12) - risk (6) $=6$

money $(7,11,19,31)$ - economy-inflation $(16)-\operatorname{selling}(8,19,20)=9$

Table 2. Lexical Relations Final Essay Case Study 1

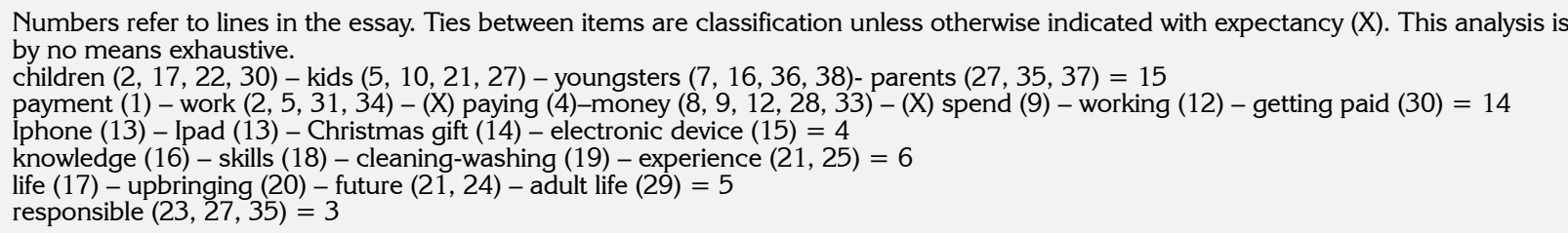


after school - why not? But never should the work be a replacement for school or take too many hours a day. Also it should not be a one-sided routine work, because this would lack the children the possibility to try out many different activities as they should in order to develop well. There is nothing to say against showing children different types of work in order to prepare them for their later life. But this should happen according to their age, and it will not necessarily be a good thing, if the child is not prepared enough to understand the aim of the activity. A child has no chance to understand [...] (lines 19-31)

This was something that $\mathrm{AL}$ also seemed to recognise in her post-instruction interview:

[...] in the first essay I just wrote from the beginning to the end more or less in one paragraph [...] I didn't structure the main body of the text that well, uhm... I didn't...erm... structure my thoughts that well into different arguments. It was more like...erm... just writing in the way I was thinking.

Regarding lexical cohesion, $14 \%$ of words entered into lexical relations in AL's initial essay, as shown in Table 3 below.

On the other hand, AL's final essay in week eight (appendix D) showed that her effort to apply the PEE model in various sections of her text, i.e. in the second, fourth, and fifth paragraphs (lines 6-15, 22-29 and 30-36 respectively) seemed to result in a clearer, more structured and more logically organised response e.g. [POINTS] “... gain professional skills [...] learn about how the job market works and how difficult it can be to earn money" (lines 8-11), [EXAMPLE] “... a child helps his or her parents in the shop..." (lines 13-15). This seeming improvement in the cohesion and coherence of her final essay was something AL also agreed with in her post-instruction interview:

Interviewer: "OK, and do you see that model, the PEE model, applied in any of your two essays, either the initial or final essay?

AL: "Yes, I applied it; I tried my best to apply it in the second one, in the final essay."

Interviewer: "OK. Now, during the teaching sessions of the past few weeks we have looked at the IELTS criteria for marking essays which includes task completion, cohesion and coherence, lexical resource, and grammatical range and accuracy. Do you think that the PEE model has helped you improve in any of these areas?

AL: "Yes. Certainly with cohesion and coherence."

Interviewer: "Cohesion and coherence (echoing answer). Could you elaborate on that a bit more? I mean, what... in which way has the model helped you?"

AL: "Well... structure my argument and make the text more readable (mispronounced), easier to read."

She seemed to elaborate on improvements of cohesion and coherence related to the structure of her final essay:

"You can see already from the layout that it's better structured. I have other paragraphs with empty lines in between, as you recommended me, and yes... I thought much more about the structure and about the paragraphs [...]"

"[...] in the second one I thought more about structure, and... so in the second one everything is more simple, I think. So I really had only these three or four arguments and not much more,

Table 3. Lexical Relations Initial Essay Case Study 2

Numbers refer to lines in the essay. Ties between items are classification unless otherwise indicated with expectancy (X). This analysis is by no means exhaustive.

children $(1,9,13,15,16,19,24,26,34,39,41)$ - child $(2,6,29,31)$-household's (5) - families (9) - parents (11, 41) - household (32) - adult (33) $=21$

(X) forced to work (1) - labour $(2,7,32)$ - work $(3,4,9,18,21,23,27,35)$ - (X) make a living (12) - activity (31)-money (5, 9) income $(5,33)$ - resources $(12,13)$ - financial support $(38)$ - economy $(41)=22$

children (1)-(X) play (15) - (X) learn $(16,19)$ - educated (16) - (X) develop talents (17) - school $(19,21,22,34)$ - (X) doing activity (20) - activities (25) - (X) develop (25) - teachers (38) - education (39) - institutions (37) = 16 
whereas in the first essay I tried to give as much information as possible."

Regarding lexical cohesion, $15 \%$ of words formed lexical strings in AL's final essay, as shown in Table 4 below.

The findings of this case study also suggested that AL found the PEE model particularly useful in regard to the clarity that can be added to an IELTS-related essay, as articulated in her post-instruction interview

Interviewer: "OK. And now, comparing the two essays, do you see any differences in the way you developed your ideas in both essays?"

AL: "Yes, of course. As I said, I thought about the structure of the single argument much more. I really tried to have just one reason or argument in one paragraph...

Interviewer: "... that's in the final essay..."

AL: "Yes, in the final. So that's a big difference.

My thoughts in the final one were much clearer."

The findings here also suggested that although AL found the PEE model useful in regard to the structure that can be given to an IELTS-related essay, she considered the model a further writing tool or choice rather than a necessity"

\footnotetext{
AL: "The PEE model? Yes, it is definitely very useful... erm... especially...erm... as a preparation for the IELTS exam, I think. It helped me to think more about how I write, how I structure an argument, and it made me try to find out more about it and to read more about it, and of course it doesn't cover everything possible but it's a very good start, I think." "[...] my final is much better than the initial essay and I have a different approach now to writing...erm... I
}

know that these three things PEE- Point, Explanation, Example - I don't have to apply them, it's just a possibility to help me but it works really well."

\section{Common occurrences in both case studies}

In their initial interviews, both students articulated explicit awareness of some elements as part of wellwritten essays (e.g. generic structure). However, this knowledge had not seemed to materialise in their initial essays.

In their initial interviews, both students assessed planning as an important stage in the essay writing process, but both failed to make a written plan for their initial essays. On the other hand, after having worked on planning strategies during the instruction, both students made written plans for their final essays. This seemed to improve the organisation of their ideas.

In both cases, the structure appeared to improve in the final essays, it showed similarities, i.e. the body of the essay sandwiched between an introductory and a concluding paragraph. Although both students had received instruction on ways to organise writing through thematic patterns, only JR employed a split thematic pattern in her final essay.

The lexical relations in both final essays appeared to be longer and more frequent, suggesting a stronger focus on themes and a more adequate selection of lexis.

\section{Discussion}

These findings suggest that Cole's (2013) PEE model is seemingly effective in improving the cohesion and coherence of students' essays, but such

Table 4. Lexical Relations Final Essay Case Study 2

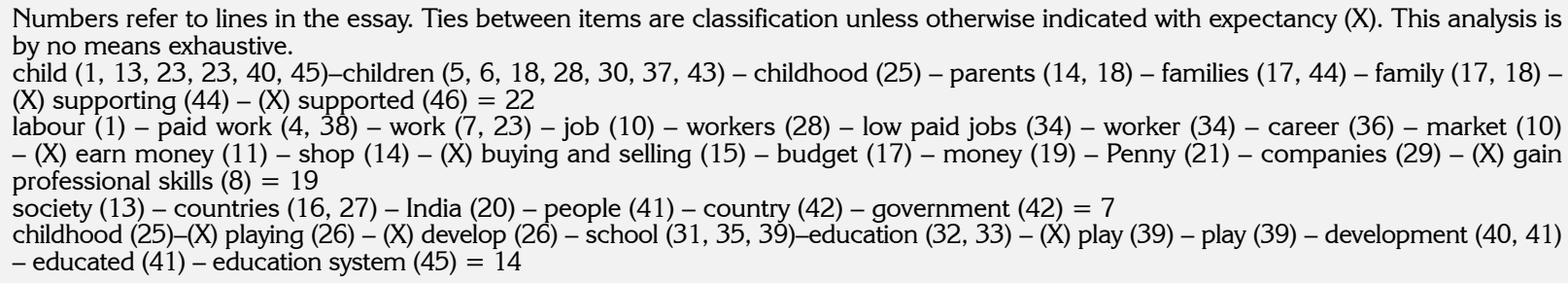


improvements may be unlikely to occur solely as a result of the application of such a model, and further work on other elements like essay planning strategies, essay structure, and lexical relations may be needed to truly see advances in cohesion and coherence.

These findings also suggest that there are inconsistencies between the theoretical knowledge students have and what they actually put into practice when performing under pressure. This could simply be a reflection of Messick's (1996) recognition that students get affected by negative washback resulting from writing under exam conditions.

These findings seem to echo the belief that writing in general is a never-ending process, and writing essays, as Golder and Coirier (1996) and Gleason (1999) argue, does pose high cultural, linguistic, and pragmatic demands onto EFL students. Findings also seem to add to the ideas previously put forward by Davies (1988), in which in order to master intricate genres such as essays, students need to be given practice in subtleties occurring at both top-down and bottom-up levels of writing.

One implication of the PEE model for ESL teaching is that although the model seems to have a more positive than negative effect on the essaywriting performance of IELTS students, such a model should not be portrayed as a replacement of other writing approaches. On the contrary, it should serve as a complementary tool embedded in a wider teaching ideology.

The findings of this research should be treated with caution due to the very nature of the study. These findings are indeed particular to the context in which this study was carried out and should not be considered as common occurrences that apply to all IELTS contexts.

A number of recommendations could be considered in future studies. First, in line with Archibald's (2002) research, higher quality assessment material could help to avoid potential issues with reliability of data. Second, the roles of teacher and researcher could be assigned to different people to help the objectivity of the study, i.e. marking could be carried out by external trained IELTS assessors. Third, the instruction relating to the PEE model could be imparted in sessions separate from the regular instruction to give essaywriting training a greater focus. Last, in order to provide further evidence of application and impact of what has been learned through instruction (recommended by Boston University, 2013; HeriotWatt University, 2014), students could write a third essay sometime after the instruction to assess their ability to produce a coherent-cohesive essay through the application of the PEE model.

New directions for future research could look at: the application of the PEE model using a quantitative approach with IELTS preparation groups from different institutions; or the extent to which the model is effective with learners at specific bands within the IELTS scale-to expand on Green and Weir's (2002) findings that students within the lower spectrum of the IELTS bands tend to progress more than those within higher ones; or the application of the PEE model to oral argumentation in debates in general or within the IELTS speaking module.

\section{Conclusion}

Based on two case studies, this study investigated the application of the PEE model to essay composition in a multi-lingual IELTS preparation class. The findings of this study suggest that the PEE model is to some extent effective in improving the essay composition performance of IELTS students, in particular in the area of cohesion and coherence, as identified in both the essay analyses and interviews. Students find the PEE model useful in regard to the clarity and structure that the model seems to add to their essays. However, the PEE model only appears to be a relatively small but seemingly positive contribution to the bottomup essay writing practice IELTS students ought to be given, at least until they understand and master more complex essay-writing argumentation skills required at tertiary level such as Ramsay, Maier, and Price's (2010) AER model. 


\section{References}

Archibald, A. (2002). Managing L2 writing proficiencies: Areas of change in students' writing over time. International Journal of English Studies, 1(2), 153174.

Bathia, V. (1993). Analysing genre: Language use in professional settings. Harlow, UK: Longman.

BBC. (2013). Structure: Tips for answering questions, KS3 Bitesize. Retrieved from http:/www.bbc.co.uk/ bitesize/ks3/english/reading/structure/revision/6/.

Bello, T. (1997). Improving ESL learners' writing skills. ESL Resources Digest. Retrieved from http://www. cal.org/caela/esl_resources/digests/writing.html.

Biber, D. (1988). Variation across speech and writing. Cambridge: Cambridge University Press.

Bill, G. (2010). Case study research methods. London: Continuum International. Retrieved from http:// site.ebrary.com/lib/portsmouth/docDetail. action?docID $=10404926$

Black, M., \& Capel, A. (2006). Objective IELTS. Cambridge: Cambridge University Press. Boston University. (2013). Pre and post testing. Retrieved from www.bumc.bu.edu/fd/files/PDF/Pre-andPostTests.pdf

Brown, J. (1998). An investigation into approaches to IELTS preparation, with particular focus on the academic writing component of the test. In S. Wood (Ed.), IELTS Research Reports Volume 1(pp. 20-37). Sydney: ELICOS/IELTS Australia.

CGP. (2012). GCSE English writing skills: The study guide for the GCSE English, English language E English literature specifications. Cumbria: Coordination Group Publications Ltd.

Cheng, F. (2008). Scaffolding language, scaffolding writing: A genre-approach to teaching narrative writing. Asian EFL Journal, 10(2), 167-191.

Coomber, J. (1998). Are test preparation programs really effective? Evaluating an IELTS preparation Course. Unpublished MA dissertation, University of Surrey.

Cole, D. (2013). Paragraph coherence: The PEE model. Retrieved from http://www.dcielts.com/ielts-writing/ paragraph-coherence-1/.

Davies, F. (1988). Designing a writing syllabus in English for academic purposes: Process and product. In P. Robinson (Ed.), Academic writing: Process and product, ELT document 129 (pp. 130-142). Hong Kong: Macmillan Education.

Denscombe, M. (2010). The good research guide for small-scale social research projects $\left(4^{\text {th }} \mathrm{ed}\right.$.). Berkshire: Open University Press.
Dudley-Evans, T. (1994). Genre Analysis: an approach to text analysis for ESP. In M. Coulthard (Ed.), Advances in written text analysis (pp. 219-228). London: Routledge.

Eggins, S. (2004). An introduction to systemic functional linguistics. London: Continuum.

Elder, C., \& O'Loughlin, K. (2003). Investigating the relationship between intensive EAP training and band score gain on IELTS. In IELTS Research Reports Volume 4 (pp. 207-254), Canberra: IELTS Australia.

Flower, L., \& Hayes, J. R. (1977). Problem solving strategies and the writing process. College English, 39, 449-461.

Freebody, P. (2006). Qualitative research in education. London: SAGE Publication.

Gabrielatos, C. (2000a). EFL Writing: Product and Process (Part 1): Looking below the surface. ELT News, 133, 18. ERIC Accession Number ED476839.

Gabrielatos, C. (2000b). EFL Writing: Product and Process (Part 2): Elements of good writing. ELT News, 134, 12-13. ERIC Accession Number ED476839.

Gabrielatos, C. (2000c). EFL Writing: Product and Process (Part 3): A teaching framework. ELT News, 135, 26-27. ERIC Accession Number ED476839.

Golder, C., \& Coirier, P. (1996). The production and recognition of typological argumentative text markers. Argumentation, 10, 271-282.

Gleason, M. (1999). The role of evidence in argumentative writing. Reading \& Writing Quarterly, 14, 81-106.

Green, A., E Weir, C. (2002). Monitoring score gain on the IELTS academic writing module in EAP programmes of varying duration. Phase 1 report. Cambridge: UCLES.

Green, A., \& Weir, C. (2003). Monitoring score gain on the IELTS academic writing module in EAP programmes of varying duration. Phase 2 report. Cambridge: UCLES.

Halliday, M. A. K., \& Hasan, R. (1976). Cohesion in English. London: Longman.

Halliday, M. A. K., \& Matthiessen, C. M. I. M. (2004). An introduction to functional grammar ( $3^{\text {rd }}$ ed.). London: Edward Arnold.

Harrison, M., \& Whitehead, R. (2006). IELTS practice tests with key. Boston: Thompson ELT.

Heriot-Watt University. (2014). Pre and post testing? Institute for computer based learning. Retrieved from www.icbl.hw.ac.uk/ltdi/cookbook/info_pre_and_ post/printable.pdf

Horner, B., \& Min-Zhan, L. (1999). The birth of basic writing. Urbana, I.: National Council of Teachers of English. 
Hyland, K. (2000). Disciplinary discourses: Social interactions in academic writing. Harlow, UK: Longman.

Hyland, K. (2003). Second language writing. Cambridge: Cambridge University Press.

Hyland, K. (2006). English for academic purposes: An advanced resource book. Abingdon: Routledge.

IELTS. (2013). IELTS task 2 writing band descriptors (public version). Retrieved from http://www.ielts.org/ PDF/UOBDs_WritingT2.pdf.

Jakeman, V., \& McDowell, C. (1999). Insight into IELTS. Cambridge: Cambridge University Press.

Jakeman, V., \& McDowell, C. (2004). Step up to IELTS. Cambridge: Cambridge University Press.

Jarvis, D. (2002). The process writing method. The Internet TESL Journal, 8(7). Retrieved from http:// iteslj.org/Techniques/Jarvis-Writing.html.

Keck, C. (2006). The use of paraphrase in summary writing: A comparison of L1 and L2 writers. Journal of Second Language Writing, 15(4), 261-278.

Kongpetch, S. (2006). Using a genre-based approach to teach writing to Thai students: A case study. Prospect, 21(2), 3-33.

Kozloff, M. (2014). Experimental research. University of North Carolina. Retrieved from www.uncw.edu/ people/kozloffm/experiments.doc

Matsuda, P., E Silva, T. (2010). Writing. In N. Schmitt (Ed.), An introduction to applied linguistics (2 ${ }^{\text {nd }}$ ed.) (pp. 232-246). London: Hodder and Stoughton.

May, P. (2004). IELTS practice tests with explanatory key. Oxford: Oxford University Press.

McCarthy, M. (1991). Discourse analysis for language teachers. Cambridge: Cambridge University Press.

Messick, S. (1996). Validity and washback in language testing. Language Testing, 13, 241-256.

Moore, T., \& Morton, J. (1999). Authenticity in the IELTS academic module writing test: A comparative study of task 2 items and university assignments. Retrieved from https://www.ielts.org/PDF/Vol2_Report4.pdf.

Neff-van Aertselaer, J., \& Dafouz-Milne, E. (2008). Argumentative patterns in different languages: An analysis of metadiscourse markers in English and Spanish texts. In Putz, M. \& Neff-van Aertselaer, J. (Eds.), Developing contrastive pragmatics interlanguage and cross-cultural perspectives (pp. 87-102). Berlin/New York: Mouton de Gruyter.

Olivas, M., E Li, C. (2006). Understanding stressors of international students in higher education: What college counsellors and personnel need to know. Journal of Instructional Psychology, 33, 217-222.
Ramsay, P., Maier, P., \& Price, G. (2010). Study skills for business and management studies (1 ${ }^{\text {st }}$ ed.). Essex: Pearson.

Scrivener, J. (2011). Learning teaching ( $3^{\text {rd }}$ ed.). Oxford: Macmillan.

Sidaway, R. (2006). The genre-based approach to teach writing. In English! Spring issue, 24-7.

Steele, V. (1992). Product and process writing: A comparison. Rowley: Newbury House.

Swales, J. (1990). Genre analysis. Cambridge: Cambridge University Press.

Swales, J. (2004). Research genres: Explorations and applications. Cambridge: Cambridge University Press.

TES. (2008). PEE Chain: A PowerPoint presentation showing example of point, evidence $\mathcal{E}$ explanation using Louis Sachar's Holes. Retrieved from http://www.tes.co.uk/teaching-resource/PEEChain-3008070/.

UCLES. (2007). Official IELTS practice materials. Cambridge: IELTS Organisation.

Ur, P. (2012). A course in English language teaching. Cambridge: Cambridge University Press.

Wall, D., Nickson, A., Jordan, R., Allwright, J., \& Houghton, D. (1988). Developing student writing: A subject tutor and writing tutors compare points of view. In P. Robinson (Ed.), Academic writing: Process and product: ELT document 129 (pp. 117-129). Hong Kong: Macmillan Education

White, R. (1980). Teaching written English. London: George Allen and Unwin.

White, R., E Arndt, V. (1991). Process writing. Harlow: Longman.

Wilkinson, D., E Birmingham, P. (2003). Using research instruments: A guide for researchers. London: Routledge.

Woodrow, L. (2006). English in academic setting: A postgraduate course for students from non-English speaking backgrounds. In M. A. Snow \& L. KamhiStein (Eds.), Developing a new course for adult learners (pp. 197-218). TESOL Publications.

Yin, R. (1994). Case study research: Design and methods ( $2^{\text {nd }}$ ed.). California: Sage Publications.

Yu, G. (2009). The shifting sands in the effects of source text summarizability on summary writing. Assessing Writing, 14(2), 116-37.

Yuan-Shan, C., E Shao-Wen, S. (2011). A genre-based approach to teaching EFL summary writing. ELT Journal, doi: 10.1093/elt/ccro61. Retrieved from http://eltj.oxfordjournals.org 


\section{Appendices}

\section{Appendix A - Initial Essay Case Study 1 (over two pages)}

Writing Task 2

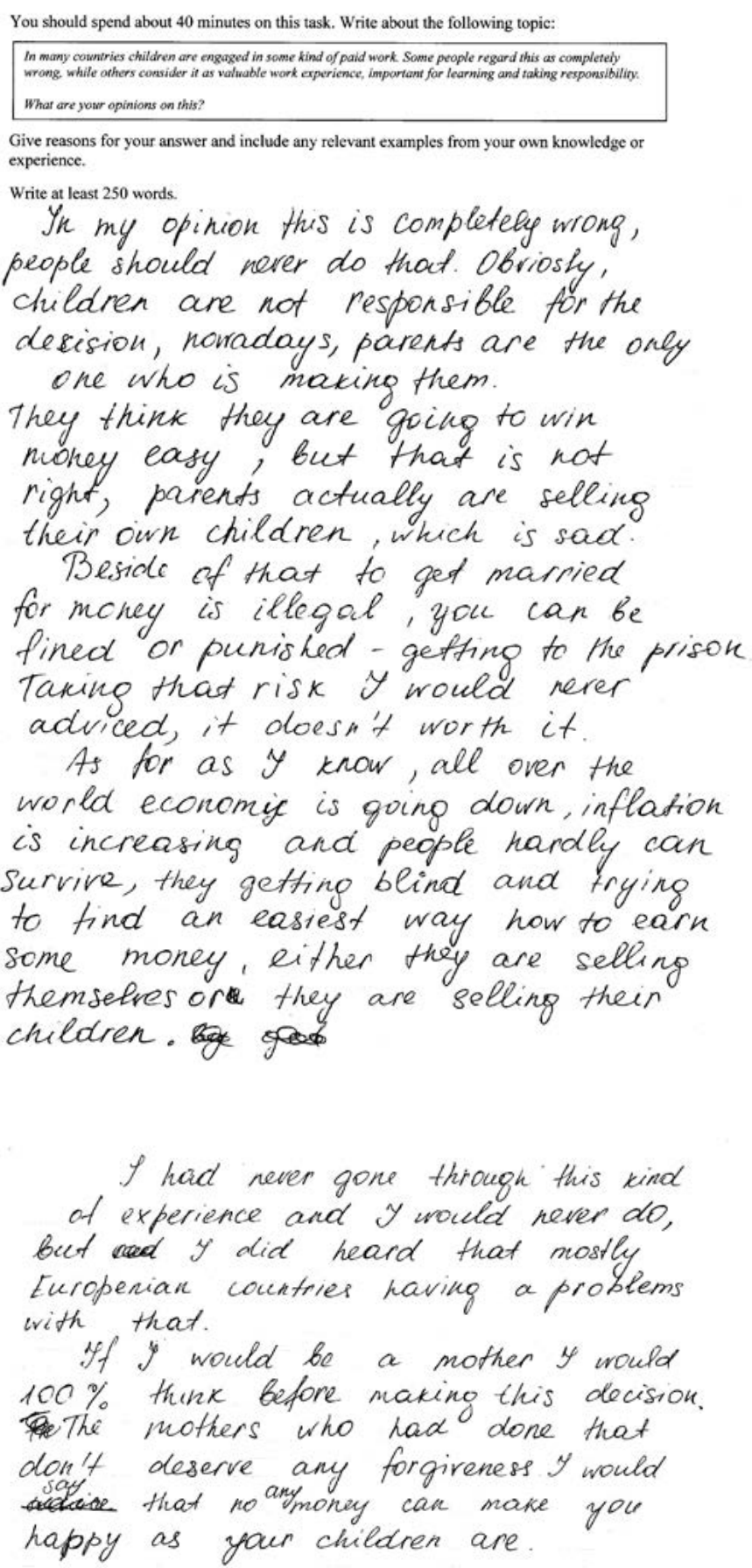




\section{Appendix B - Final Essay Case Study 1 (over two pages)}

Writing Task 2

You should spend about 40 minutes on this task. Write about the following topic:

In many countries children are engaged in some kind of paid work. Some people regard this as completely
wrong, while others consider it as valuable work experience, important for learning and taking responsibility.
What are your opinions on this?

Give reasons for your answer and include any relevant examples from your own knowledge or experience.

Write at least 250 words.

There are mixed views regarding the payment
to ohildren for some kind of work. yt is deneraly
accepted that this is right, howerer pthers
consider opposite. Y tend to think that paying
kcds for work is paramount for thre
reasons?

Firstly, youngsters would understand the ralue of money in other words they will have their own money to spend whateren they desire. of also ridsy will thelerstand thew hard porents are-workito to get lmove for

have an idea how huerd parents are working to get money. In that case, instead of asting for an Iphohe or I pad as a tha a
electronic derice.

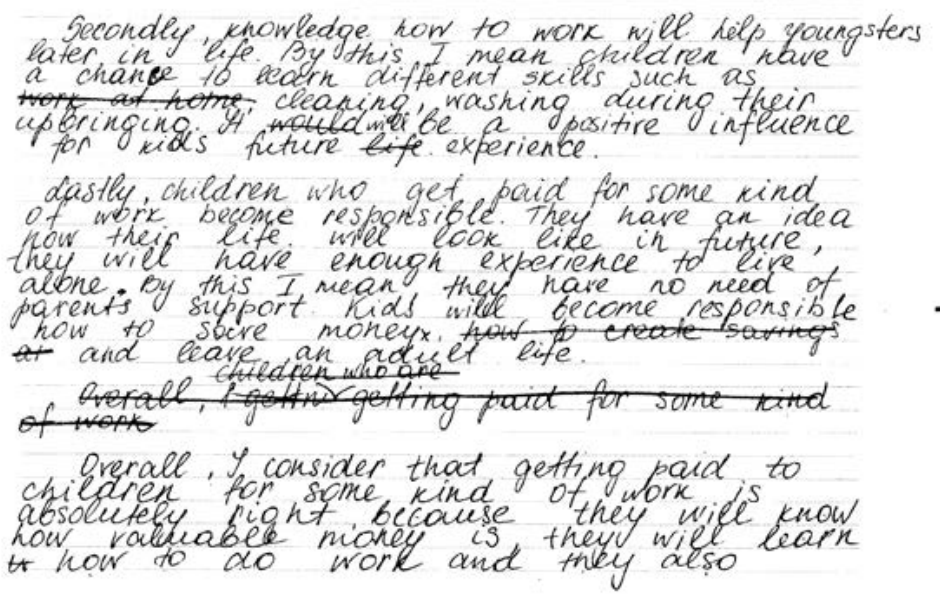

will be responsible. I would advice parents to engage their youngsters to work it would help porents as much as it nould help youhosters. 


\section{Appendix C - Initial Essay Case Study 2 (one page)}

\section{Writing Task 2}

You should spend about 40 minutes on this task. Write about the following topic:

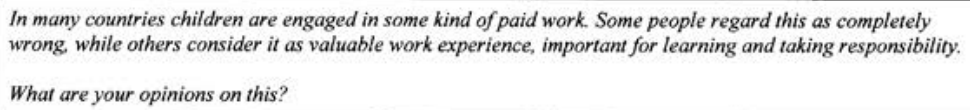

Give reasons for your answer and include any relevant examples from your own knowledge or experience.

Write at least 250 words.

Children sheuld not be farced to work. Not only is this my personal goinion, but also is child labow fortidden todlaly in many countries. When I Use the usard "urark" here, I nean work, that will be said and thus " contenplate

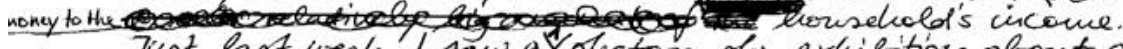
Just last week I tow at photograghy exhibition about drild labour which was convion will 100 years ago. And even foday there are suany counties, where children have to work for money, because their fanilie's aretoo poor, or because there is woone who cares for them. Sometimes it is understandable that parents try to use the recouces they have to suake a living, and in a way their children are a recource. But just because it is understaudable it does not mean it is a grod thing. children should be given the porsibieity to play and to learn. Children stwoild be educated in different directions, so that they con develop their talcuts and chose the right field of work accorching to their abilities and cinterests later in life. Children should go to school. If they can learn something by doring another activity for some time affer school - why not? But vever skould the wark be a replacenent for shool or take too, many hours a day. Acso it scould not be a one-sided rontine work, because this would lack the children the possibility to try out many different activities as they should in order to develop well. There is uothing to say against showing childeren different types of work in ordenati prepare them for thetr later life. But this should according to their age, and it will mot necessarily be a good thing, if the child is not prepared enongh to ctuderstand the chim of the activity. A child has wo chonce to mederstandit is used for something like the labour warket or houseliald incoune as long as no adult explains it to bin.

That's why children should have the right to go to school every where in the world, and to mot wark. Also, of course, it should be one of the mast impartant goals of politic of all countries to provide the needed institutions, infrar structure, speciatists (teadrers and so on) and financial sryport for the education of thetr children. This will, withont any doubt, improve the development of the country, and it wille be the best for children, pareuts and the economy.

$\hat{V}$ shocking $V^{2}$ for example in New York 


\section{Appendix D - Final Essay Case Study 2 (over two pages)}

\section{Writing Task 2}

You should spend about 40 minutes on this task. Write about the following topic:

In many countries children are engaged in some kind of paid work. Some people regard this as completely wrong, while others consider it as valuable work experience, important for learning and taking responsibility.

What are your opinions on this?

Give reasons for your answer and include any relevant examples from your own knowledge or experience.

Write at least 250 words.

child labour is a very confroversial topic on which

there are many different opinions. In this essay / crould

like to the most inportant arguments

concerning the pros and contras of paid work when

engaging children.

There is undonbtedly one huge advantage, when children are introdnced to different binds of work. They get the chance to gain proferrional skills early which they night need at a later stage of life again. At the same time they learn about how the job nuares works and kow difficult it can be to earn noney. Because of that burowledge they night have a more realistic picture of the society. If a cliter helps his or her parents in the shop, he or she will cunderstand the process of buying and selling.

In poorer counties, this night be a necessity in nany fanilies, when the fanily budget is not ewough. - If the Gildren holp the parents, the fauily coill have nore money. I have seen examples of that in India, where on some days there is just not 
On the other haud, we should not forget how kasily a chied can be wisused for work. A cluied Shas no chance to understand that it might be lacked of its childkood and does not get the time for playing it should have in order to develop in all directions. It happens in many conntries sfill today that children are used as workers big comparies.

Connected to this is also the fact that the children can not go to school at the soune time and don't get a good education. This creates a circle, because without education they will stay in low paid jobs for their eutire life. A worker who did not finish school has little prospects of mabing a successful career.

In suy givion, children slowld not be involved in paid work, if this means that they it go to sclusel and play enongh Play is ersential for the development of a dild, and well educated people are essential for the deuelopvent of a country. Every government should focus on how to enowre children get what they need, which rueaus supporting poor fouilies and improving the education system. Every cuild deserves to be supported.

\section{(c) (i) $\odot$}

